\title{
Introduction - Beckett, Medicine and the Brain
}

\author{
Elizabeth Barry $^{1}$ • Ulrika Maude ${ }^{2}$ - Laura Salisbury ${ }^{3}$
}

Published online: 10 March 2016

(C) Springer Science+Business Media New York 2016

When Samuel Beckett's library was opened up to scholars, it gave some sense of the extraordinary amount of material that had been funnelled into the development of a writer so famed for his minimalism. Alongside an extensive array of books that spoke to his literary interests, there were texts suggestive of medical and scientific concerns, a number of dictionaries and the eleventh edition of Encyclopaedia Britannica. Some sections of the encyclopaedia were clearly marked by Beckett, and there is a folded page that suggests an entry over which he may have lingered: "Brain". Beckett did dog-ear pages in books that interested him though there is no way of knowing definitively if he was the one who pressed down this page; still, Dirk Van Hulle and Mark Nixon note, somewhat conservatively, that "Brain" "could conceivably have interested Beckett" $(2013,193)$. Indeed, as this issue of the Journal of Medical Humanities demonstrates, the brain and its functioning was of abiding, particular interest to Beckett. Scholars now know that Beckett took extensive notes (held in Trinity College Dublin) on contemporary psychology and psychoanalysis in the 1930s; he also read medical text books and the neurological conditions they detailed with more attention than one would expect from a casually interested amateur. But then, there was nothing casual about Beckett's anatomising of the mind and body in his work. From the 1930s, when he began to write creatively in a sustained fashion, until the final parched utterances of the 1980s, the tensely discordant relationship between mind and body and the functioning of the brain - the site where mind and body are most insistently implicated - remain key thematic interests for Beckett and produce an extraordinary push and pull on the form of his texts. It is certainly hard to think of a non-medically-trained writer who has returned more insistently to the

\section{Elizabeth Barry}

e.c.barry@warwick.ac.uk

Ulrika Maude

ulrika.maude@bristol.ac.uk

Laura Salisbury

L.A.Salisbury@exeter.ac.uk

1 Department of English and Comparative Literary Studies, University of Warwick, Coventry CV4 7AL, UK

2 Department of English, University of Bristol, 3/5 Woodland Road, Clifton, Bristol BS8 1 TB, UK

3 Department of English and Film, University of Exeter, Room 221, Queen's Building, Queen's Drive, Exeter EX4 4QH, UK 
phenomenological experience of disorder and the technical language of neurological and psychological dysfunction. Equally, it is hard to think of another writer who has a stronger sense of the potential of disorder and dysfunction to scuff up the window of internal representation that, in health, can render our experience so smoothly continuous, so transparent, that one only looks through it rather than at it. Like scratches on a pane of glass, Beckett's articulations of disorder and disease work to denude experience of its occulting clarity, as they render grittily explicit the uncomfortable disjunctions between idea and expression, mind and body, free will and automaticity, continuity and rupture, endurance and senescence that are as much a part of human experience as the evenness of wellbeing.

Born in 1906 and keen from the start to explore the the mind/body problem in his writing, it is perhaps not surprising that Beckett was engaged by the ways in which the mind was becoming increasingly linked to the functioning of cerebral matter and an extended nervous system. In the 1860 s, neurology had already determined that language, and perhaps even the thought it seemed to subtend, might be localized within particular areas of the cortex, while by the 1870s, the nervous system had been firmly reconceived as something that worked according to reflex functions - material impulses that had themselves been 'clocked' at between 35 and 45 metres per second in 1867. In 1879, psychology definitively followed the lead of the natural and physical sciences in their models of systematized experimentation, observation and the meticulous recording of accumulated data when Wilhelm Wundt founded the first active psychological laboratory in Leipzig - a move mirrored by William James's establishment of the Harvard Psychological Laboratory in America. Earlier psychological study had been dependent upon introspection and philosophical models of self-analysis, with psychology mostly undertaken literally as psyche logos, the study of the soul. But as Beckett read in the 1930s when he undertook his study of contemporary schools of psychology and psychoanalysis, the research in Wundt's psychological laboratory definitively moved away from introspection towards the study of performance as well as experience: "The question up for investigation might be how quickly [a subject] could react, or how accurately he could perceive, or how completely he could recall material he had memorized; [...] he was not asked to report his experience during the task, but simply to perform his task' (Woodworth 1931, 10). Psychophysics, in particular, refused introspection or a philosophy of memory in favour of constructing thought - that which is most essential to the self - as a material function within an objectively analysable system.

Psychoanalysis, which emerged from nineteenth-century neurology but split into its own discipline at the beginning of the twentieth century, turned to a topographical account of the functioning of the mind in the face of the difficulty of converting the developing science of brain centres and nerve pathways into a model of mental functioning that could account for the complexity of psychological disorder. But a bridge between experimental psychology, neurology and psychoanalysis remained in a shared insistence that the mind was determinedly linked to neurophysiology and structured according to scientifically analysable systems of functioning over which the self had profoundly limited conscious control. Alongside many other twentieth-century writers, Beckett was an inheritor of the idea that the conscious human subject was never strictly coterminous with or "at home" to itself. Beckett, however, was to make conscious use of the newly anatomised automaticity of much mental functioning, alongside both the hyperassociative and dissociative qualities of mental illness and the compulsive corporeality of the neurologically disordered body. For Beckett, what the new sciences of the brain offered were languages and striking symptoms that precisely interrogated the human subject's hold on its prized categories of free will, intention and rationality. 
From the beginning, critical analyses of Beckett's work have pursued the intuition that an ungraspable mind and its troubled relationship to an unruly body was Beckett's primary material. This placed the brain centre stage, and as Beckett's work from the late 1950s through the 1960s persistently affirmed, if one were to demand precise coordinates for his imagined white cylinders, rotundas and strangely abstracted non-spaces, the only rather occluding response the texts could offer would be that "we are, needless to say, in a skull" (Beckett 1995, 70). In the 1960s, criticism certainly interpreted Beckett's skullscapes as affirming a broadly existentialist humanist concern with portraying the human mind thrown back on itself, stripped of the normative social habits that mask its uninhabitable strangeness. This loosely psychological mode was consolidated and extended in the next few decades, as critics of various theoretical schools undertook detailed and revealing readings of both the content and form of Beckett's work in relation to specifically psychoanalytic ideas. Anxious to understand the movements, enactments and articulations of the texts rather than simply to psychoanalyze either author or characters, many scholars produced rich analyses of the performance of modes and drives within the work - modes, it turned out, that could usefully be understood through the ideas of psychoanalysis, even though they could not happily be reduced to them.

During the 1990s, however, critics such as Jean-Michel Rabaté, Phil Baker and J. D. O'Hara began to note the odd specificity of terms relating to neurological and psychological dysfunction that seemed to creep into Beckett's texts. And a new path for those interested in Beckett's particular reworking of the raw materials of brain and mind was broken when, in his biography Damned to Fame (1996), James Knowlson revealed the cache of notes on psychology and psychoanalysis that Beckett had taken between 1934 and 1935 when he started psychotherapy with Wilfred R. Bion. Beckett worked with Bion as a way of addressing his own disabling symptoms that, from a contemporary point of view, resemble those of an anxiety disorder. Though his typed notes suggest an attempt to gain an intellectual, abstract understanding of mental and neurological functioning, they also bear witness to a sense of anxious recognition of his own psychological and somatic difficulties. Without wishing to reduce Beckett's engagement with psychology and neurology to pathography, it is nevertheless vital to note that Beckett was as interested in the phenomenological experience and affective consequences of disorder as he was in understanding the mind and body as systematically connected.

It is, we think, worth documenting the contents of Beckett's "Psychology Notes" - notes to which the author, either consciously or not, returned throughout his writing career. They begin with transcriptions from the Bloomsbury psychoanalyst Karin Stephen's Psychoanalysis and Medicine: A Study of the Wish to Fall Ill (1933) that explore Freudian theory, while Freud's own New Introductory Lectures on Psychoanalysis are précised under the heading of "Id, Ego \& Superego". R. S. Woodworth's Contemporary Schools of Psychology (1931) seems to offer Beckett a technical overview of a field in its account of late nineteenth-century experimental psychology, behaviorism (including the work of Watson, Thorndike and Pavlov), neurological theories of the localization of functions in the brain, the Gestalt psychology whose terms make their way into the early novel Murphy (1938), and accounts of the psychoanalytic theories of Alfred Adler and Jung. Beckett's knowledge of Freudian theory is extended by his reading of Ernest Jones's Papers on Psychoanalysis (1923), while subsequent notes on Jones's Treatment of Neuroses (1920) and its material on conversion hysteria and the psychogenic causes of physical ailments contain levels of detail and sardonic personal ejaculations that suggest some sort of identification with the symptoms presented. Wilhelm Stekel's Psychoanalysis and 
Suggestion Therapy (1923) is quickly condensed by Beckett into a few useful terms (including "[a]cathisia, i.e., inability to sit down", which appears in the figure of Cooper in Murphy), but Alfred Adler's The Neurotic Constitution (1921) is attended to in far greater detail, with its descriptions of how the neurotic's will is both narcissistically engorged as a will to power and paralysed in symptoms. Beckett's final notes on Otto Rank's The Trauma of Birth (1929) follow in detail the thesis that all neurosis is an expression of the trauma of birth, as the baby is expelled from intrauterine calm, from the realm of pure pleasure, into the world. For Rank, as for Freud, the pleasure principle and the death drive are folded into one another, with pleasure's aim of returning the organism to the state of quiescence that precedes birth compellingly elided with an unconscious fantasy of the experience of death. Beckett had already explored an idea of a "wombtomb" before reading Rank, but knowing that Beckett preserved Rank's technical account of the drives that underpin a feeling that implicates birth and death and finds a sense of rapturous extinction in a never quite to be inhabited nothing, does assist the critical work that would seek to understand how and why particular drives and demands occupy such a central place in Beckett's texts.

Beckett also had a more wide-ranging interest in medicine and medical discoveries. In addition to works on psychology and psychoanalysis, he read more general medical textbooks such as Sir Willam Osler's highly influential The Principles and Practice of Medicine, which was translated into a number of languages and ran into many editions. From Osler's chapter on alcoholism, Beckett adopted the word "cyanosis", the reddening of the face which is a symptom of chronic alcoholism. The term recurs in a number of Beckett's works (see Beckett 2014, 103). From Pierre Garnier's anti-masturbation publication, Onanisme seul et a deux sous toutes ses forms et leurs consequences, which Beckett read in Trinity College Dublin library in 1931 in the book's ninth or tenth edition, Beckett picked up strands of narrative, curious terminology, and an emphasis on the mechanical nature of sexuality, which, as Yoshiki Tajiri has noted, is often likened to "pistons, cylinders and switches" in his early writing $(2007,195)$. Hypersexuality, in particular, figures prominently in Beckett's early prose works, Dream of Fair to Middling Women (completed 1932; published 1992) and More Pricks than Kicks (1934). He also read Max Nordau's Degeneration, and from it he acquired details about neurological conditions such as Tourette's syndrome and male hysteria, which Jean-Martin Charcot (1825-1893), who had been Nordau's tutor, had researched intensively in the last fifteen years of his life.

Beckett's interest in medicine is part of the wider engagement modernist writers had with medical culture. James Joyce (2008), with whom Beckett had a close personal friendship and whose work profoundly influenced the young Beckett, began the study of medicine three times during his life, but on each occasion he abandoned his studies. Unsurprisingly, medical ideas greatly influenced Joyce's work, especially his most famous novel Ulysses (1922). In the Gilbert and the Linati schemata of the novel, Joyce gave most of the episodes their own "organ", including the "kidney", "genitals", "heart", "lung", "brain" and "nerves". The organ of "The Oxen of the Sun" episode of Ulysses is the womb/uterus. The episode combines a focus on the development of the English language with a parodic narrative of human gestation, and it is set in Holles Street National Maternity Hospital in Dublin. In 1920, during the writing of the episode, Joyce drew a gestation chart to which he added nine notes on foetal development (now held in the Cornell University Library Joyce Collection). The episode playfully satirizes gendered attitudes towards childbirth but also has a more serious undertone: in the background, throughout the novel, looms Bloom and Molly's dead child, Rudy, victim of the "infant mortality" mentioned in the episode. The presence of Rudy here and elsewhere in the 
novel attests to the gravity with which Joyce's novel critiques the gendered nature of the medical culture of the day. For while rapid progress had been made in numerous fields of medicine, others, such as obstetrics, lagged behind, partly because childbirth was seen as the domain of midwives and hence unworthy of the attention of male surgeons. Infant mortality in Ireland in particular was scandalously high, and Joyce's work can be seen as paradigmatic of the way in which modernist literature, although formally drawing on a number of medical advances, simultaneously challenges some of the assumptions of medicine's broader practical culture.

Medicine, and in particular neurology and psychiatry, were also crucial to the development of surrealism. A number of the key surrealists, including André Breton, Théodore Fraenkel, Louis Aragon and Max Beckman, had either studied psychiatry or had worked as doctors or orderlies in the medical services during the Great War, and they would have had first-hand experience of brain-injured and shell-shocked soldiers. Language pathology therefore had its role to play in the development of surrealism, and Beckett had an intimate knowledge of surrealist literature. In 1928, he translated "The Fiftieth Anniversary of Hysteria," by Louis Aragon and André Breton, which advocated hysteria not as "a pathological phenomenon" but as "a supreme form of expression" (Breton 1978, 321). Between 1929 and 1932, Beckett translated many more surrealist texts for the modernist little magazine, transition, for Nancy Cunard's Negro Anthology (1934), and most importantly, for the "Surrealist Number" of the journal This Quarter 5:1, published in 1932. Over fifty pages of the journal's two hundred odd pages were translated by Beckett (Sardin and Germoni 2011, 740). Among the texts Beckett translated during this period are passages of The Immaculate Conception by Breton and Paul Éluard, in which the essays simulate mental illnesses for literary effect, "maladies virtual in each one of us [that] could replace most advantageously the ballad, the sonnet, the epic, the poem without head or tail, and other decrepit modes" (Breton 1978, 51). For the surrealists, mental illness liberated language from convention, in turn enabling the linguistic experimentation endemic to modernist writing.

Beckett's engagement with the work of the surrealists reflects his own preoccupation with the involuntary nature of much language use both in pathology and in everyday life. While medical conditions arguably have a more subtle and complex relationship to linguistic style in his own work than that of his surrealist counterparts, there is a common understanding of the embodied nature of writing and the arbitrary nature of the line between pathology and health. The first article of this issue opens up some of these concerns. Russell Smith's piece reflects the recent turn towards affect and emotion in literary studies, focusing on the neglected topic of anger in Beckett's work. Beckett once said memorably, "[a]11 I am is feeling"; emotion is at once central to his writing and strangely elusive there, confounding attempts to harness it to the lyrical or the intersubjective. To balance other readings in this issue that engage with what might be called the pathological mind in Beckett's work, Smith refutes the idea that rage is a clinical symptom, reading it rather as a drive or compulsion that might yield psychic pleasure as well as harm. Anger, he suggests, may even be a component of well-being, as it appears in Aristotle and other Greek thought. Reading Beckett in the light of these depathologizing accounts of anger, as well as the psychoanalyst Alfred Adler's notion of the "masculine protest" (Beckett took notes from Adler's two volumes, The Neurotic Constitution and Individual Psychology, in the 1930s), Smith distinguishes in Beckett's work and elsewhere the conflicting energies of the (constructive) thymos, or will-to power, and the irritation and compensatory neurotic 'superiority' that impose inaction - the latter condition familiar from Moran's narrative in Molloy in particular but encountered frequently in the trilogy. Countering 
this irritable mode, Smith argues, can be found a syntax of rage (rather than the more familiar weakness) operating throughout the trilogy, an implacable energy born of liberated and even heroic anger.

Rina Kim's article also explores the perplexing presentation of emotion in Beckett's work. For Kim, Beckett's brain is resolutely material, and she traces the implications of this for his articulation of feeling. She reflects on his interest in the 'gaps' in brain structure - the "synaptic chasm" he talked about to Lawrence Shainberg $(1987,102)$ - and draws an analogy with the centrality of discontinuities and absences in his own aesthetic practice. The article also argues that what Lois Oppenheim has called the "biological accuracy" $(2005,80)$ of Beckett's writing makes it productive to read representations of both consciousness and brain pathology in his work in the light of recent discoveries in neuroscience. We can in this way identify his prescience and the nature of his insights into the relations between material brain (the "liquefied brain" to which Becket alludes in The Unnamable) and conscious and unconscious 'mind'. Kim notes that Beckett's exploration - ironic and otherwise - of the biological basis of emotion pre-empts the claims of psychoanalytic interpretation, something that Piette will go on to situate historically in relation to the competing disciplines within what might broadly be termed "brain science".

Exploring a more sinister dimension to the "liquefied brain", Adam Piette opens up a dramatic moment in the history of material treatment of the mind, exploring the foray that Beckett's post-war trilogy makes into these physical and mental realms (the psychiatric institution, the mind of the lobotomy patient) in relation to key aspects of the historical and political moment of writing. If the trilogy appears to move away from politics as its subject breaks down, or is broken down, under psychiatric treatment, to write of brutal and extreme psychiatric practice in the late 1940s is, as Piette argues, necessarily to engage with politics in the shape of the political uses of psychosurgery during the Cold War. The striking imagery of lobotomy in Malone Dies and in particular The Unnamable where the skull wall is pierced, drilled, and lights shone in on the protagonist's mind sits uncomfortably but resonantly alongside a subject whose words are judged and punished but who can no longer remember his crimes. His radically material treatment is an assault not only on the Freudian unconscious - drives and desires he cannot consciously summon - but also the psychoanalytic method that might uncover it through intersubjective 'talk' - a conflict being played out in the history of the time when psychosurgery was seen as a brutal corrective to the "suspiciously elaborate" and potentially subversive practice of depth psychoanalysis.

Next, the issue features a dialogue between a psychiatrist (Matthew Broome) and creative practitioner (Jonathan Heron) that explores as its context a psychiatry as far as one can be from the brutal and repressive psychiatric methods of the Cold War. The impulse behind this intellectual and ethical conversation is a reflection on two models of understanding the patient as subject - the ideographic whereby the person is seen as an irreducible and unique event, and the nomothetic, where the clinician (in this case) relies on general laws to understand them (Broome 2008) - and the way in which Beckett's theatre might allow for an exploration of both modes. These ways of encountering another individual originate in the philosophy of Wilhelm Windelband, which Beckett read and transcribed in the 1930s, and - as this dialogue demonstrates - are thematized in Beckett's 1976 play Rough for Theatre II. If the Cold War psychiatric subject is reduced to dumb materiality by the most invasive means, the subject in Beckett's play is victim of a very different treatment: a cold detachment which reduces the living subject to a collection of documents and a handful of questionable symptoms and classifications. In both cases, the affective dimension of treatment is lost and with it a rich 
source of understanding - an understanding that the methods of practical theatre and performance analysis can, as this dialogue shows, bring to life. Beckett's use of the theatrical mode itself invokes two processes within theatre practice and analysis analogous to the ideographic and the nomethetic: the phenomenological and the semiotic, whereby a production may be conceived in terms of the nervous system of the actors and audience, or of the system of signs in which the disembodied 'object' of the play consists. The silent body in Beckett's play - the documented subject standing at a window and contemplating suicide - is both sign and subject of a suffering that he and the audience must stare in the face.

In another article that considers Beckett's work in relation to the philosophy of psychiatry, Elizabeth Barry returns to the vexed question of the relationship between Beckett's work and the condition of schizophrenia. Putting aside existing approaches such as Beckett's reflection of the idea of schizophrenia as cultural symbol or the putative connections between the language of Lucky or the Unnamable and the schizoid patient, this article focuses on the disruption to ipseity, the pre-reflective self-awareness that Beckett (after Nordau) identified as coenaesthesis, which Beckett's characters - in common with those with schizophrenia appear to suffer, as well as the cognitive, somatic and perceptual effects of such a disruption. Like Kim, Barry explores the significance of this pre-reflective level of consciousness for Beckett's presentation of self. The writer's work, Barry suggests, offers a subjective perspective on experiences that could be seen to characterize psychotic illness - a perspective that points to underlying links between the affective aspects of the condition and the deficits it often produces in attention, memory and time perception. It might be fruitful, she argues, for the student of Beckett to think about how philosophers of psychiatry describe linguistic selfreference under the pressure of psychosis, descriptions that might be compared productively to those in Beckett's mature work. Beckett's writing, in turn, might offer imaginative models that would assist clinicians in understanding schizophrenia as a disorder of self, as much recent philosophy of psychiatry has tried to encourage, and in so doing help them to make sense of its assault not only on affect and communication but also on cognitive and perceptual function.

The penultimate article opens up concerns with the nature of language and agency that are central to the issue as a whole. Considering Beckett in relation to two very different thinkers with whom he was familiar, Henri Bergson and Samuel Johnson, Ulrika Maude explores the concerns of all three with habitual, automatic and involuntary behaviour. Beckett's reading of Nordau is again critical in this regard, Nordau's concern with 'degeneracy' sharing the preoccupations of nineteenth-century neurologists with involuntary behaviour as manifested in conditions such as Tourette's syndrome. For all of these writers, the human is, as Maude puts it, "inflicted by the mechanical", not only in the grip of language pathologies that impose automatisms of speech but in their everyday utterances and behaviour. Johnson was for Beckett not only a model stylist (if one inflicted with something of the mechanical, a "wit and wisdom machine" [Beckett, cited in Smith 2002, 115]) but also a specimen of fascination as a man - a man whose obsessions and verbal and physical tics were for Beckett as eloquent as his witticisms. While Bergson contests the "recalcitrance of matter" and the habitual as it encroaches upon speech and gesture, Beckett can be seen to embrace this tendency, finding in it some truth about the fundamental limitations of our intentionality in relation to language, behavior and thought.

Finally, in a second pairing of humanities scholar and scientist, Laura Salisbury (a literary critic) and Chris Code (a neuropsychologist) return to the theme of linguistic automatism, probing the connections between Beckett's writing and those models of language and language disorder that challenge the idea that linguistic ability underlies the human's status as rational 
animal. ${ }^{1}$ They look in particular at the theories of the late nineteenth-century neurologist John Hughlings Jackson, whose work on the neurological underpinnings of language chimes compellingly with Beckett's creative explorations of disordered language and experiences akin to aphasia, a condition with which Beckett was intimately familiar. They suggest that Beckett's work is in dialogue - unwitting or otherwise - with that of Hughlings Jackson in so far as it is particularly attuned to aspects and uses of language that might be seen to be automatic and non-propositional - and to language's connection with the fragile materiality of the brain, also examined here in different contexts by Kim, Maude and Piette. Operating in the space between "I can't" and "I must", as Salisbury and Code put it (after Beckett) - Beckett's work invokes both the "incompleteness" and the emotionally charged "modalizing" compulsions of the aphasic speaker and translates both into an aesthetic which challenges the certainties of knowledge while preserving an affective and expressive power.

As this and the other articles in this issue show, the scope of Beckett's exploration of functions and dysfunctions of the brain works as a way of asking fundamental questions of the contours and limits of selfhood and representation. ${ }^{2}$ By drawing together scholars, practitioners and clinicians interested in investigating how Beckett's use of neurological and psychological discourses shapes his work, while exploring how the aesthetic experiences those texts produce might help us to understand and contain the complexity of the subjective experience of illness and disorder, this special issue hopes to tease out how Beckett's particular knotting of the language of brain science and of art comes to bind together and articulate a relationship between critical and clinical concerns.

Acknowledgements The editors would like to acknowledge the great support given to the work in this issue by eminent Beckett scholar Professor Mary Bryden, who died shortly before it went to press. The issue is dedicated to her memory.

\section{Endnotes}

${ }^{1}$ This article is a revised version of a chapter of the same title published in Literature, Speech Disorders and Disability: Talking Normal, edited by Chris Eagle (London: Routledge, 2013), which is reproduced by permission of Taylor and Francis Group, LLC, a division of Informa plc.

${ }^{2}$ This special issue represents a body of work that emerged from a year-long programme of interdisciplinary events on the topic of Beckett and Brain Science funded by the UK's Arts and Humanities Research Council.

\section{References}

Adler, Alfred. 1917. The Neurotic Constitution: Outlines of a Comparative Individualistic Psychology and Psychotherapy. Translated by Bernard Glueck and John Lind. New York: Moffat, Yard and Company.

Baker, Phil. 1997. Beckett and the Mythology of Psychoanalysis. London: Macmillan.

Beckett, Samuel. 1990. The Complete Dramatic Works. London: Faber. 1995. The Complete Short Prose: 1929-1989. Edited by S. E. Gontarski. New York: Grove Press.

Breton, André. 1978. What Is Surrealism? Selected Writings of André Breton. Edited by Franklin Rosemont. New York: Monad Press.

Broome, Matthew R. 2008. "Philosophy as the Science of Value: Neo-Kantianism as a Guide to Psychiatric Interviewing." Philosophy, Psychiatry, Psychology 15:107-116.

Jones, Ernest. 1913. Papers on Psychoanalysis. London: Baillière, Tindall and Cox.

- 1920. Treatment of Neuroses. London: Baillière, Tindall and Cox.

Joyce, James. 2008. Ulysses. Edited by Jeri Johnson. Oxford World's Classics. Oxford: Oxford University Press. 
Knowlson, James. 1996. Damned to Fame: The Life of Samuel Beckett. London: Jonathan Cape.

O'Hara, J. D. 1997. Samuel Beckett's Hidden Drives: Structural Uses of Depth Psychology. Gainesville: University of Florida Press.

Oppenheim, Lois. 2005. A Curious Intimacy: Art and Neuro-Psychoanalysis. Hove: Routledge.

Rabaté, Jean-Michel. 1996. The Ghosts of Modernity. Gainesville: University of Florida Press.

Rank, Otto. 1929. The Trauma of Birth. London: Kegan Paul, Trench, Trubner.

Salisbury, Laura and Chris Code. 2015. "Jackson's Parrot: Samuel Beckett, Aphasic Speech Automatisms and Psychosomatic Language.” Journal of Medical Humanities 37 (2).

Sardin, Pascale and Karine Germoni. 2011. "Scarcely Disfigured': Beckett's Surrealist Translations." Modernism/modernity. 18 (4): 739-753.

Shainberg, Lawrence. 1987. "Exorcising Beckett." The Paris Review 104:100-36.

Smith, Frederik N. 2002. Beckett's Eighteenth Century. Basingstoke: Palgrave Macmillan.

Stekel, Wilhelm. 1923. Psychoanalysis and Suggestion Therapy. Translated by James S. Teslaar. London: Kegan Paul, Trench, Trubner.

Stephen, Karin. 1933. Psychoanalysis and Medicine: A Study of the Wish to Fall Ill. Cambridge: Cambridge University Press, 1933.

Tajiri, Yoshiki. 2007. Samuel Beckett and the Prosthetic Body: The Organs and Senses in Modernism. Basingstoke: Palvrave Macmillan.

Van Hulle, Dirk, and Mark Nixon. 2013. Samuel Beckett's Library. Cambridge: Cambridge University Press.

Woodworth, Robert S. 1931. Contemporary Schools of Psychology. London: Methuen. 